\title{
Milk Tea Industry: An Exploratory Study
}

\author{
Fhrizz S. De Jesus, MBA, LPT
}

\begin{abstract}
This study entitles "Milk Tea Industry: An exploratory study" aims to determine the increasing popularity of milk tea industry. Its main objective is to identify and assess the profile of the respondents, the 4Ps of marketing product, price, promotion and place and the SWOT analysis strength, weaknesses, opportunity and threats.
\end{abstract}

This study made use of the descriptive normative research to determine the increasing popularity of milk tea industry in the areas of Bongabon, Nueva ecija. This method quantitatively describes specific details of specific groups. The descriptive survey and interview were used in gathering information on the increasing popularity of milk tea industry. It is descriptive in nature since it is limited in determining the current status of the problem at hand.

According to the gathered data most of the respondents are highly considering the quality of the products in their businesses. Based on the results of assessment on the SWOT analysis the respondents are highly considering the convenience and fast service, quality ingredients and creating of loyal customers in their business.

All milk tea shop owners in Bongabon regardless of their demographic and business profile are highly considered the marketing strategies when it comes to their businesses. Each of them have their own unique strategies.

Keywords - milk tea, product, price, promotion, place, strength, weaknesses, opportunity, threat.

\section{INTRODUCTION}

According to Weiner (2009), people are more adventurous and love to try new taste and experiment on new flavors. They love everything that is fresh, exciting and beneficial to them. It is evident that there a continuous demand for the milk tea industry since it was on trend and new in the market

This study will focus on the growing popularity of milk tea and its establishment within the municipality of Bongabon. This study will assess the milk tea industry base on the profile of the business, the 4P's of marketing and the SWOT analysis if it has a significant relationship with the increase of marketing popularity of milk tea.

The researcher aims to provide recommendations that will give solutions to the increasing demand of the milk tea industry.

\section{OBJECTIVES OF THE PROBLEM}

This research based on the study of Ilusorio (2014) entitled "Increase of Popularity of Milk Tea in the vicinity of Mendiola" have found out the real reason why milk tea is to be seen in demand in Mendiola and discovered what is in milk tea that makes people crave for it given what they only know about the product.
This study aims to describe and assess the milk tea industry. Specifically, the study sought answers to the following questions:

1.How may the profile of the respondents be described in terms of:

1.1 Sex

1.2 Age

1.3 Civil status

1.4 Years of operation

1.5 Types of ownership

1.6 Average monthly income

2.How may the popularity of milk tea industry be assessed in terms of:

2.1 Product

2.2 Price

2.3 Promotion

2.4 Place

3.How may the milk tea industry be assessed in terms of:

3.1 Strength

3.2 Weakness

3.3 Opportunity 


\subsection{Threats}

\section{METHODOLOGY}

This study made use of the descriptive normative research to determine the increasing popularity of milk tea industry in the areas of Bongabon, Nueva Ecija. This method quantitatively describes specific details of specific groups.

The research instrument used in this study was survey method wherein the respondents answered questions administered through questionnaires and interviews.

The instrument was formulated in the modified 4-point likertscale ranging from strongly agree (4), agree (3), disagree (2), strongly disagree (1). Respondents were then instructed to rate the statements and answer the questions.

The data collected from the locale were encoded, tallied and analyzed. The following statistical tools were used. Data presentation of the given scale was used to interpret the results of the information gathered:

To determine the respondents degree of perception the weighted mean was computed using the formula: Weighted mean $\left(\sum \mathrm{WM}\right)$ is equal to total weighted frequency ( $\left.\sum \mathrm{WF}\right)$ divided by the total number of cases $(\mathrm{F})$.

The percentage frequency distribution was computed using the formula: frequency $(\mathrm{F})$ divided by the sample $(\mathrm{N})$ and multiply by one hundred (100). The researcher used ranking to compare items to each other by placing them in order of preferences.

\section{RESULTS AND DISCUSSION}

According to the gathered data:

Table.1: Demographic Profile According to Sex

\begin{tabular}{|c|r|c|}
\hline PROFILE & F & $\%$ \\
\hline VARIABLE & SEX & \\
\hline MALE & $\mathbf{2}$ & $\mathbf{2 5 \%}$ \\
\hline FEMALE & $\mathbf{6}$ & $\mathbf{7 5 \%}$ \\
\hline
\end{tabular}

Table 1 shows the demographic profile of the respondents in terms of sex. Majority of the respondents who participated in the interview were females with a number of six (6) or seventy-five percent (75\%) outsourcing the number of two (2) or twenty-five percent (25\%) that males emerged on.

Generally, Municipality of Bongabon is dominated by males but females are more interested in managing the milk tea business.

Table 2. Demographic Profile According to Age

\begin{tabular}{|c|c|c|}
\hline PROFILE VARIABLE & F & $\%$ \\
\hline \multicolumn{2}{|c|}{ AGE } & \\
\hline $15-25$ & 3 & $38 \%$ \\
\hline $26-35$ & 1 & $12 \%$ \\
\hline $36-45$ & 3 & $38 \%$ \\
\hline $46-55$ & 1 & $12 \%$ \\
\hline 55 up & 0 & $0 \%$ \\
\hline
\end{tabular}

For the age range of the respondents, Table 2 presents the age range of fifteen to twenty five (15-25) and thirty six to forty five (36-45) years of age comprised thirty eight percent (38\%) of the respondents. They formed the majority group and were followed by the group that belonged to the age range of twenty six to thirty five (26-35) and forty six to fifty five (46-55) years of age who comprised the next highest percentage of twelve percent (12\%).

The above findings indicated that majority of the respondents were in the age of 15-25 years old and 36-45 years old followed by 2635 and 46-55 years old. These findings point to the fact that the respondents are more teenagers and middle-aged adults. During the interview conducted, the respondents who are teenagers said that their love for the milk tea was the reason why they put up milk tea business. On the other hand, middle-aged adults said that the trend of milk tea products was their reason to put up this kind of business. Local milk tea shops are emerging everywhere, taking advantage of the craze and catering to the taste of teenagers and young adults.

Table 3. Demographic Profile According to Civil Status

\begin{tabular}{|l|l|l|}
\hline PROFILE VARIABLE & F & $\%$ \\
\hline CIVIL STATUS & & \\
\hline Single & 5 & $63 \%$ \\
\hline Married & 2 & $25 \%$ \\
\hline Widow/Widower & 1 & $12 \%$ \\
\hline Separated & 0 & $0 \%$ \\
\hline
\end{tabular}

Table 3 visualizes the business profile of the respondents in terms of the civil status wherein the most number of respondents were 
single with five (5) individuals or sixty three percent (63\%). And those who were widow or widower were least in number with one (1) person obtaining twelve percent (12\%) of the respondents.

Majority of the respondents were single because of age reason, 15 years old and above. Single individuals are more likely to invest in a milk tea business. On the interview conducted, they said that the increasing popularity of milk tea was the reason why they put up this kind of business. They also said that massive number of students getting in on the trend, buying milk tea allowed milk tea shops to thrive.

Table 4. Business Profile According to Years of Operation

\begin{tabular}{|l|l|l|}
\hline $\begin{array}{l}\text { PROFILE } \\
\text { VARIABLE }\end{array}$ & F & $\%$ \\
\hline \multicolumn{2}{|l|}{ YEARS OF OPERATION } & \\
\hline Less than 1 year & 7 & $88 \%$ \\
\hline 1-2 years & 1 & $12 \%$ \\
\hline 3-4 years & 0 & $0 \%$ \\
\hline 5-6 years & 0 & $0 \%$ \\
\hline 7-above & 0 & $0 \%$ \\
\hline
\end{tabular}

For the years of operation, Table 4 presents the years of business with less than one year with seven (7) or eighty eight percent $(88 \%)$ of the respondents. They formed the majority group and were followed by the group that belonged to the one to two years of business operation with one (1) or twelve percent (12\%) who comprised the next highest percentage.

The above findings indicated that majority of the respondents were less than one year of business operation followed by one to two years. These findings point to the fact that the large numbers of respondents are new with the milk tea business. During the interview conducted, the respondents said that they are new with milk tea business because milk tea is recently discovered and gaining popularity in the local market. Milk tea trend was officially back and local milk tea shops are emerging everywhere.

Table 5. Business Profile According to Types of Ownership

\begin{tabular}{|l|l|l|}
\hline PROFILE & F & $\%$ \\
\hline VARIABLE & & \\
\hline TYPES OF OWNERSHIP & \\
\hline Sole Proprietorship & 4 & $50 \%$ \\
\hline Partnership & 4 & $50 \%$ \\
\hline Corporation & 0 & $0 \%$ \\
\hline
\end{tabular}

Table 5 visualizes the business profile of the respondents in terms of types of ownership wherein sole proprietorship and partnership had the same number of respondents with four (4) individuals or fifty percent (50\%) respectively.

The findings indicated that majority of the business owners were sole proprietorship and partnership. These findings point to the fact that commonly the owner of the milk tea business was sole proprietor or partnership.

Table 6. Business Profile According to Average Monthly Income

\begin{tabular}{|l|l|l|}
\hline PROFILE VARIABLE & F & $\%$ \\
\hline AVERAGE MONTHLY INCOME & \\
\hline $\mathbf{P 5 , 0 0 0 - 1 0 , 0 0 0}$ & 0 & $0 \%$ \\
\hline $\mathbf{P 1 5 , 0 0 0 - 2 0 , 0 0 0}$ & 2 & $25 \%$ \\
\hline $\mathbf{P 2 5 , 0 0 0 - 3 0 , 0 0 0}$ & 2 & $25 \%$ \\
\hline $\mathbf{P 3 5 , 0 0 0 - 4 0 , 0 0 0}$ & 1 & $12 \%$ \\
\hline $\mathbf{P 4 5 , 0 0 0 - 9 0 , 0 0 0}$ & 3 & $38 \%$ \\
\hline
\end{tabular}

Table 6 visualizes the business profile of the respondents in terms of average monthly income wherein forty-five thousand to ninety thousand pesos ( $(\mathcal{P} 45,000-90,000)$ or thirty eight percent $(38 \%)$ of the respondents. They formed the majority group and were followed by the fifteen to twenty thousand pesos ( $\mathrm{P} 15,000-20,000)$ and twenty five to thirty thousand pesos ( $(\mathrm{P} 25,000-30,000)$ or twenty five percent $(25 \%)$ of the respondents. And thirty-five thousand to forty thousand pesos ( $(35,000-40,000)$ were least in number with one (1) person obtaining twelve percent (12\%) of the respondents.

The above findings indicated that the common average monthly income of the milk tea business range from forty five to ninety thousand pesos ( $\mathrm{P} 45,000-90,000)$. These findings point to the fact that number of milk tea fans keep growing as milk tea shops keep popping up. Love for milk tea is at an alltime high.

Table 7. 4Ps of Marketing: Product

\begin{tabular}{|c|c|c|c|}
\hline INDICATORS & WM & RANK & DESCRIPTION \\
\hline $\begin{array}{l}\text { Materials and } \\
\text { ingredients used } \\
\text { in milk tea are } \\
\text { important } \\
\text { elements in } \\
\text { production. }\end{array}$ & 4 & 1 & Strongly Agree \\
\hline
\end{tabular}




\begin{tabular}{|c|c|c|c|}
\hline $\begin{array}{l}\text { Taste is a factor } \\
\text { in selling milk } \\
\text { tea. }\end{array}$ & 4 & 1 & Strongly Agree \\
\hline $\begin{array}{l}\text { Colorful features } \\
\text { of packaging } \\
\text { attract the } \\
\text { customer to buy } \\
\text { milk tea. }\end{array}$ & 3.62 & 3 & Strongly Agree \\
\hline $\begin{array}{l}\text { Incorporation of } \\
\text { creativity and } \\
\text { innovativeness in } \\
\text { the product. }\end{array}$ & 3.87 & 2 & Strongly Agree \\
\hline $\begin{array}{l}\text { Use of brand } \\
\text { name to sell the } \\
\text { product. }\end{array}$ & 3.5 & 4 & Strongly Agree \\
\hline $\begin{array}{l}\text { Availability of } \\
\text { numerous } \\
\text { numbers of } \\
\text { flavors. }\end{array}$ & 3.5 & 4 & Strongly Agree \\
\hline $\begin{array}{l}\text { Customizing the } \\
\text { taste of product } \\
\text { based on } \\
\text { customer } \\
\text { preference. }\end{array}$ & 3.87 & 2 & Strongly Agree \\
\hline $\begin{array}{l}\text { Standard } \\
\text { procedures are } \\
\text { used in the milk } \\
\text { tea production. }\end{array}$ & 4 & 1 & Strongly Agree \\
\hline $\begin{array}{l}\text { General } \\
\text { Weighted Mean }\end{array}$ & 3.80 & & Strongly Agree \\
\hline
\end{tabular}

Table 7 below presents the effects of marketing strategy of the business in terms of product. The researcher found out that the materials and ingredients, taste and standard procedure of a milk tea are the factors to be considered in a milk tea product with a weighted mean of 4 .

These findings pointed the fact that the milk tea shop owners are highly considered the materials and ingredients, taste and standard procedure of the milk tea they are selling. Taste of a milk tea often attracts consumers that are seeking new milk tea varieties to savor. Consumers are more likely to choose a milk tea that can satisfied their cravings.

Table 8. 4Ps of Marketing: Price

\begin{tabular}{|l|l|l|l|}
\hline INDICATORS & WM & RANK & DESCRIPTION \\
\hline $\begin{array}{l}\text { Customers buy milk } \\
\text { tea because of its } \\
\text { affordability. }\end{array}$ & 3.75 & 2 & Strongly Agree \\
\hline $\begin{array}{l}\text { Uses price discounts } \\
\text { to increase sales. }\end{array}$ & 3.12 & 5 & Agree \\
\hline
\end{tabular}

\begin{tabular}{|l|l|l|l|}
$\begin{array}{l}\text { Price lists are } \\
\text { available and } \\
\text { presented to the } \\
\text { customers. }\end{array}$ & 4 & 1 & Strongly Agree \\
\hline $\begin{array}{l}\text { Provide PWD and } \\
\text { senior citizen } \\
\text { allowance/discount. }\end{array}$ & 3.5 & 3 & Strongly Agree \\
\hline $\begin{array}{l}\text { The price of the milk } \\
\text { tea is value based } \\
\text { from its taste. }\end{array}$ & 3.25 & 4 & Agree \\
\hline $\begin{array}{l}\text { Income is based on } \\
\text { the percentage of the } \\
\text { price mark-up. }\end{array}$ & 2.87 & 6 & Agree \\
\hline $\begin{array}{l}\text { General Weighted } \\
\text { Mean }\end{array}$ & 3.41 & Strongly Agree \\
\hline
\end{tabular}

Table 8 presents the effects of marketing strategy of the business in terms of price. The researcher found out that the price lists that are presented to the customers, has an effect when they are buying a milk tea with a weighted mean of 4 .

These findings pointed the fact that the price list of the milk tea that is presented to the consumers has a huge impact to them. The price list helped them to choose the milk tea they want and see the price of it.

Table 9. 4Ps of Marketing: Promotion

\begin{tabular}{|c|c|c|c|}
\hline INDICATORS & WM & RANK & DESCRIPTION \\
\hline $\begin{array}{l}\text { Direct selling provides } \\
\text { information to the } \\
\text { consumers. }\end{array}$ & 3.37 & 2 & Strongly Agree \\
\hline $\begin{array}{l}\text { Outdoor advertisement } \\
\text { (such as tricycle tarpaulin, } \\
\text { jeepney stickers etc.) } \\
\text { encourages customer to } \\
\text { buy a milk tea. }\end{array}$ & 2.75 & 6 & Agree \\
\hline $\begin{array}{l}\text { Radio advertisement helps } \\
\text { the store in their sales. }\end{array}$ & 2.87 & 5 & Agree \\
\hline $\begin{array}{l}\text { Customers buy milk tea } \\
\text { because of social media. }\end{array}$ & 3 & 4 & Agree \\
\hline $\begin{array}{l}\text { The store uses different } \\
\text { promotional discounts (e.g } \\
\text { loyalty card, discount } \\
\text { coupon, unli promos). }\end{array}$ & 3.12 & 3 & Agree \\
\hline $\begin{array}{l}\text { The store has a signage } \\
\text { that can be seen in } \\
\text { morning and night. }\end{array}$ & 3.75 & 1 & Strongly Agree \\
\hline General Weighted Mean & 3.14 & & Agree \\
\hline
\end{tabular}


Table 9 presents the effects of marketing strategy of the business in terms of promotion. The researcher found out that the store signage that can be seen in morning and night help the consumers to see where the shop is located with a weighted mean of 3.75 .

These findings pointed the fact that the milk tea shop signage that can be seen in morning and night are one of the factors to be considered by the owners to help the customers to easily locate their shops. Signage help owners to promote their business because it draws attention to the consumers and it help them to differentiate the shops from the others.

Table 10 presents the effects of marketing strategy of the business in terms of place. The researcher found out that the location of the shop if it is located near the town and if it is safe and secured for the public is also one factor to be considered to gain more consumers with a weighted mean of 3.87 .

These findings pointed the fact that the milk tea shop location helps the business to have more consumers. A good location is important to the success of a business. It helps them to improved revenue and increased marketing exposure.

Table 10. 4Ps of Marketing: Place

\begin{tabular}{|c|c|c|c|}
\hline INDICATORS & WM & DESCRIPTION & RANK \\
\hline Product & 3.80 & Strongly Agree & 1 \\
\hline Price & 3.41 & Strongly Agree & 3 \\
\hline Promotion & 3.14 & Agree & 4 \\
\hline Place & 3.54 & Strongly Agree & 2 \\
\hline
\end{tabular}

Table 11. Summary of 4Ps of Marketing

\begin{tabular}{|l|l|l|l|}
\hline INDICATORS & $\begin{array}{l}\text { W } \\
\text { M }\end{array}$ & RANK & DESCRIPTION \\
\hline $\begin{array}{l}\text { The store is located } \\
\text { near the town. }\end{array}$ & 3.87 & 1 & Strongly Agree \\
\hline $\begin{array}{l}\text { The store is located } \\
\text { in front of school. }\end{array}$ & 2.62 & 5 & Agree \\
\hline $\begin{array}{l}\text { The store is } \\
\text { accessible. }\end{array}$ & 3.75 & 2 & Strongly Agree \\
\hline $\begin{array}{l}\text { The store } \\
\text { atmosphere and } \\
\text { decorations are } \\
\text { appealing to the } \\
\text { public. }\end{array}$ & 3.62 & 3 & Strongly Agree \\
\hline $\begin{array}{l}\text { Store hours cater } \\
\text { the customers } \\
\text { dining needs. }\end{array}$ & 3.62 & 3 & Strongly Agree \\
\hline
\end{tabular}

\begin{tabular}{l|l|l|l|l|}
$\begin{array}{l}\text { The place is safe } \\
\text { and secure for the } \\
\text { public. }\end{array}$ & 3.87 & 1 & Strongly Agree \\
\hline $\begin{array}{l}\text { The store } \\
\text { underwent the } \\
\text { zoning and other } \\
\text { inspections of the } \\
\text { LGUs. }\end{array}$ & 3.5 & 4 & Strongly Agree \\
\hline $\begin{array}{l}\text { The store uses } \\
\text { feasibility study in } \\
\text { the selection of the } \\
\text { location. }\end{array}$ & 3.5 & 4 & Strongly Agree \\
\hline $\begin{array}{l}\text { General Weighted } \\
\text { Mean }\end{array}$ & 3.54 & Strongly Agree \\
\hline
\end{tabular}

Table 11 shows the comparison of each items by placing them in order of preferences. Having the Product ranked as number one (1), Place ranked as number two (2), Price ranked as number three (3) and Promotion as number four (4). The milk tea shop owners are highly considered the quality of their product as one of the factors that helps them to gain more customers. The respondents were strongly agreed based on the product.

Table 12. SWOT Analysis: Strength

\begin{tabular}{|l|l|l|l|}
\hline $\begin{array}{l}\text { INDICATORS } \\
\begin{array}{l}\text { Convenient and fast } \\
\text { service }\end{array}\end{array}$ & 4 & 1 & Strongly Agree \\
\hline $\begin{array}{l}\text { Cheaper than other milk } \\
\text { tea shop }\end{array}$ & 3.37 & 4 & Strongly Agree \\
\hline Long operating hours & 3.5 & 3 & Strongly Agree \\
\hline Marketing strategy & 3.87 & 2 & Strongly Agree \\
\hline Quality ingredients & 4 & 1 & Strongly Agree \\
\hline Discount promos & 3.87 & 2 & Strongly Agree \\
\hline Loyal customers in the & 4 & 1 & Strongly Agree \\
\hline $\begin{array}{l}\text { Innovation in } \\
\text { product }\end{array}$ & 3.87 & 2 & Strongly Agree \\
\hline
\end{tabular}

Table 12 presents the effects of SWOT analysis of the business in terms of strength. The researcher found out that the convenient and fast service, quality ingredients, and loyal customers are the factors to be considered in a milk tea industry with a weighted mean of 4 .

These findings pointed the fact that the milk tea owners are highly considered the convenient and fast service, quality ingredients, and loyal customers as the strength of their business. Quality ingredients are the most important factor 
in making a product. Also good services will help to promote a positive and friendly environment that will leave a great impression with the customer, and they will return often and likely to spend more and eventually become a loyal customers.

Table 13. SWOT Analysis: Weaknesses

\begin{tabular}{|l|l|l|l|}
\hline INDICATORS & WM & RANK & DESCRIPTION \\
\hline $\begin{array}{l}\text { Many competitors } \\
\text { within the area }\end{array}$ & 3.5 & 3.5 & Strongly Agree \\
\hline Rental fees & 3.12 & 3.12 & Agree \\
\hline Internet access & 2.87 & 2.87 & Agree \\
\hline Store capacity & 2.75 & 2.75 & Agree \\
\hline Marketing strategy & 3 & 3 & Agree \\
\hline Rainy season & 3.62 & 3.62 & Strongly Agree \\
\hline
\end{tabular}

Table 13 presents the effects of SWOT analysis of the business in terms of weaknesses. The researcher found out that during rainy season the revenue of the milk tea business were decreasing, with a weighted mean of 3.62 .

These findings pointed the fact that rainy season has a massive effects on the milk tea business in terms of their income.

Table 14. SWOT Analysis: Opportunity

\begin{tabular}{|c|c|c|c|}
\hline INDICATORS & WM & RANK & DESCRIPTION \\
\hline $\begin{array}{l}\text { New product to } \\
\text { introduce }\end{array}$ & 3.87 & 2 & Strongly Agree \\
\hline Open new branch & 3.37 & 4 & Strongly Agree \\
\hline $\begin{array}{l}\text { Introduce of brand } \\
\text { name in bigger } \\
\text { market }\end{array}$ & 3.37 & 4 & Strongly Agree \\
\hline $\begin{array}{l}\text { Create more loyal } \\
\text { customers }\end{array}$ & 4 & 1 & Strongly Agree \\
\hline Trendy product & 3.87 & 2 & Strongly Agree \\
\hline $\begin{array}{l}\text { Innovative } \\
\text { technology }\end{array}$ & 3.5 & 3 & Strongly Agree \\
\hline
\end{tabular}

Table 14 presents the effects of SWOT analysis of the business in terms of opportunity. The researcher found out that one of the opportunities that can help a milk tea business is to create more loyal customers with a weighted mean of 4 .

These findings pointed the fact that creating more loyal customers can helps the business to grow. No matter the size of the business, customer loyalty is incredibly important. One of the best and the cheapest way to reward loyal customer is to give extra perks.

Table 15. SWOT Analysis: Threats

\begin{tabular}{|l|l|l|l|}
\hline INDICATORS & WM & RANK & DESCRIPTION \\
\hline $\begin{array}{l}\text { Many } \\
\text { competitors }\end{array}$ & 3.25 & 2 & Agree \\
\hline $\begin{array}{l}\text { Seasonal } \\
\text { demand: rainy } \\
\text { season and } \\
\text { summer are } \\
\text { different }\end{array}$ & 3.62 & 1 & Strongly Agree \\
\hline $\begin{array}{l}\text { Nothing new to } \\
\text { offer }\end{array}$ & 2.75 & 4 & Agree \\
\hline $\begin{array}{l}\text { Similar concept } \\
\text { or service }\end{array}$ & 3.12 & 3 & Agree \\
\hline Price war & 3.12 & 3 & Agree \\
\hline
\end{tabular}

Table 15 presents the effects of SWOT analysis of the business in terms of threats. The researcher found out that the seasonal demand, the rainy season and summer season has an effect in a milk tea industry with a weighted mean of 3.62.

These findings pointed the fact that rainy season has a huge effects on the milk tea business in terms of their income.

Table 16. Summary of SWOT Analysis

\begin{tabular}{|c|c|c|c|}
\hline INDICATORS & WM & DESCRIPTION & RANK \\
\hline \multicolumn{4}{|l|}{ Strength } \\
\hline $\begin{array}{l}\text { Loyal customers } \\
\text { Quality } \\
\text { ingredients } \\
\text { Convenient and } \\
\text { fast service }\end{array}$ & 4 & Strongly Agree & 1 \\
\hline \multicolumn{4}{|l|}{ Weaknesses } \\
\hline Rainy season & 3.62 & Strongly Agree & 1 \\
\hline \multicolumn{4}{|l|}{ Opportunity } \\
\hline $\begin{array}{l}\text { Create more loyal } \\
\text { customers }\end{array}$ & 4 & Strongly Agree & 1 \\
\hline \multicolumn{4}{|l|}{ Threats } \\
\hline $\begin{array}{l}\text { Seasonal demand: } \\
\text { rainy season and } \\
\text { summer are } \\
\text { different }\end{array}$ & 3.62 & Strongly Agree & 1 \\
\hline
\end{tabular}

The researcher used ranking to compare items to each other by placing them in order of preferences. The first SWOT analysis of the business is strength. The researchers found out 
that the convenient and fast service, quality ingredients, and loyal customers are the top priority to be considered in a milk tea industry. The milk tea shop owners are highly considered the convenient and fast service, quality ingredients, and loyal customers as the strength of their business. Marketing strategy, discount promos, innovation in the product and long operating hours are among the top three strength of the milk tea business.

The second SWOT analysis of the business is weaknesses. The researchers found out that during rainy season the revenue of the milk tea business were decreasing. Many competitors within the area and rental fees are also their weaknesses. These findings pointed the fact that rainy season, many competitors and the rental fee has a huge effect on the milk tea business in terms of their income.

The third SWOT analysis of the business is opportunity. One of the opportunities that can help a milk tea business is to create more loyal customers. Trendy product, new product to introduce, innovative technology are also the factors that can help the business to grow.

And the last SWOT analysis of the business is threats. Seasonal demand, the rainy season and summer season, many competitors, similar concept or service and price war has an effect in a milk tea industry. These findings pointed the fact that the weakness of the milk tea business is also the threats that can affect their business in terms of their income.

Based from the findings and conclusions presented, the following are the recommendations:

1. For the SMEs, it is recommended to ensure high quality of products on top of good customer service or relation to achieve sustainability.

2. For the LGUs, security must be observed, since it is one of the best assets of a company.

3. For the DTI, the main economic catalyst that enables innovative, competitive, job generating inclusive business, and empowers consumers helps the business to be more effective and efficient.

4. For the marketing professionals, it is recommended to offer different promotional discounts (like offering loyalty cards, discount coupons, vouchers, etc.) as part of the marketing strategy to increase the demand for the product.

5. For the Milk tea industry, it is recommended to provide more varieties of milk tea to the customers (like twist of flavor, offering small cups of milk tea for affordable or cheapest price, etc.) for them to have a wider selection of choices. It should be done because of fast changing preference of the generations. Innovation is one of the strength of the milk tea business. Businesses should continue developing products according to consumers' preference. Hence, regular assessment should be done regularly.

6 . The Milk tea industry should regularly get feedback from their customers and implement innovations to their products always to ensure continued patronage and can be used as SWOT Assessment.

7. For the Milk tea industry it is recommended to provide excellent services to gain positive purchasing experience to the consumers, by doing this it may lead in increase of consumers and create loyal customers.

8. The Milk tea industry should make the atmosphere and decorations of the shop appealing to the public and ensure the safety of the consumers, it is a way of creating loyal consumers.

9. The Milk tea industry should consider the location of the shop that are accessible and can be easily seen by the customers. Some customers who experience difficulty in parking will leave the shop and lead in sales decrease.

10. Seasonal demand is one of the threats of the milk tea business, it is recommended to produce hot tea products (like hot coffee, hot chocolate, etc.) for consumers to maintain high volume of customers even during rainy season.

11. A similar study should also be conducted for other business sectors to assess their marketing strategy and develop a feasibility plan.

12. This study could serve as a basis for further business researches.

\section{ACKNOWLEDGEMENT}

The researcher would like to thank his colleagues and students from NEUST Atate Campus who provided insight and expertise that greatly assisted the research, furthermore the researcher would like to thank his Wife and Son who provided support and understanding in accomplishment of this research paper. 


\section{REFERENCES}

\section{WEBSITES:}

[1] https://www.academia.edu/30356082/Factors_Affectin g_Consumers_Buying_Behavior_on_Selected_Milk_T ea_Stores_Towards_Obtaining_Sustainability

[2] https://prezi.com/m/muxsbylk3xyk/increase-ofpopularity-of-milk-tea-in-the-vicinity-of-mendio/

[3] https://www.yummy.ph/news-trends/milk-tea-trendhistory-philippines-a00261-20190307-lfrm2

[4] http://fnbreport.ph/news/filipinos-rank-second-highestbubble-tea-drinkers-in-southeast-asia-anrii-20190502/

[5] https://www.scribd.com/doc/236482427/Significanceof-the-Study-Milk-Tea-Research

[6] http://teafever.blogspot.com/2012/03/popularity-ofdrink-milk-tea-among.html? $\mathrm{m}=1$

[7] https://www.coursehero.com/file/20095689/milk-teain-philippines/

[8] https://www.slideshare.net/mobile/OnnySamosir/chati me

[9] https://prezi.com/m/gxsw2ijag-42/case-analysis-ofinfinitea/

[10] https://www.academia.edu/9273570/OK__THESIS_FINAL_-_BSCS_FORMAT

[11] https://searchcio.techtarget.com/definition/SWOTanalysis-strengths-weaknesses-opportunities-andthreats-analysis?amp $=1$

[12] https://www.researchgate.net

\section{Books:}

[13] Liquigan, Rosario M., Nacino, Joy S. and Simangan, Richard V., MARKETING MANAGEMENT

[14] Balaria, Felipe E., MARKETING RESEARCH 